\title{
Article
}

\section{Care planning: a neoliberal three card trick}

Mckeown, Michael, Wright, Karen Margaret and Mercer, David Available at http://clok.uclan.ac.uk/15775/

Mckeown, Michael ORCID: 0000-0003-0235-1923, Wright, Karen Margaret ORCID: 0000-0003-0693-7294 and Mercer, David (2017) Care planning: a neoliberal three card trick. Journal Of Psychiatric and Mental Health Nursing, 24 (6). pp. 451-460. ISSN 1351-0126

It is advisable to refer to the publisher's version if you intend to cite from the work. http://dx.doi.org/10.1111/jpm.12356

For more information about UCLan's research in this area go to http://www.uclan.ac.uk/researchgroups/ and search for < name of research Group>.

For information about Research generally at UCLan please go to http://www.uclan.ac.uk/research/

All outputs in CLoK are protected by Intellectual Property Rights law, including Copyright law. Copyright, IPR and Moral Rights for the works on this site are retained by the individual authors and/or other copyright owners. Terms and conditions for use of this material are defined in the policies page.

\section{CLoK}

Central Lancashire online Knowledge www.clok.uclan.ac.uk

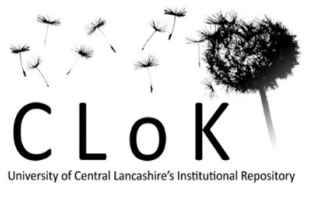




\title{
Care planning: a neoliberal three card trick
}

\author{
Mick McKeown, Karen Wright \& Dave Mercer \\ Accepted for publication: Journal of Psychiatric \& Mental Health Nursing
}

\section{Introduction}

The three card game, sometimes called find the queen, is a classic confidence trick, typically taking place on an impromptu table top, set up on pavement or street corner. The tricksters usually operate in teams, pulling in punters and 'losing' games with their fellows to persuade prospective speculators the game is winnable. For our titular purposes the three card trick serves as a metaphor for broader deceits. We are concerned with how well-meaning mental health nurses can enter into a set of apparently rational practices, insisted upon by policy and protocol, seemingly motivated by ideals of care and protection from harm, yet functioning to destroy the very essence of what it might mean to be a caring, progressive practitioner by contributing to a mutuality of alienation that, at the relational level, is the opposite of what services intend to achieve. This may prove to be the case because an external confidence trickster (neoliberalism) is actually in charge, and the real function of the game serves other ends.

The whole point of the game is that genuine players can never win, and for the trickster to triumph it is necessary that these punters are willing, gullible and in most circumstances accept losses without too much fuss. When the losers do not go quietly this is referred to in the argot of the con as 'squawking', and personnel are deployed on the periphery to ensure any squawk is minimised. Various strategies can be used to 'cool out the mark', and are analogous to the means by which people are assisted to adjust to life's disappointments in other contexts, including encounters with priests or sundry psy-professionals (Goffman 1952; McKeown et al. 2013).

This commentary paper seeks to provoke nursing out of its state of gullibility and selfdeception even if this involves painful reflection on the losses inherent in our collective game of mental health care. If we are to defend the importance of mental health nursing we must think more critically about our complicity within oppressive systems of control and do something about it. There is a lengthy critical tradition to draw on. We urge mental health nurses to squawk, asserting a more recalcitrant and rebellious standpoint, preferably in 
alliance with service users, refusers and survivors. Acknowledging the constraints upon nursing's agency, deficits of power, and structural disadvantage need not default to impotence and inaction: collective resistance is always possible, however difficult the circumstances.

\section{The set up: our argument in a nutshell}

First, we provide a critique of Neoliberalism and consequences for mental health and mental health care. Second we indicate how this might be remedied via democratisation. Care planning can be located within a wider panoply of administrative tasks that implicitly service social governance functions acceded to psychiatry from neo-liberalism under risk society (Beck 1992). We are, thus, concerned with questions of power and control in both society and the management of care and how these are worked out in consideration of politics, policy, professionalism and practice. Our aim is not to undermine rational or caring motivations to clarify needs and see these are addressed systematically. Similarly, we do not dismiss the fact that mental health nurses provide for much positive and compassionate interventions in the lives of mentally distressed people. Rather, we intend to stimulate critical thinking about the balance of effort between administrative and actual provision of care. Furthermore, we wish to expand critique about the predicament facing mental health care to open up consideration of more radical, relational, less administratively burdensome alternatives.

In various settings, but perhaps most notably within acute inpatient environs, care planning and administrative tasks that flow from it comprise the major element of nursing 'paperwork' and so-called administrative burden. Albeit the notion of paperwork has rapidly been overtaken by its digital near-relative, the computer. Unarguably, many nurses working on inpatient wards spend substantial portions of time physically removed from service users ensconced in front of computer screens. Similarly, the time that community staff spend with service users is rationed by organisational imperatives for paperwork (Simpson 2005). Both nurses and service users bemoan a lack of face to face time with each other. Paperwork has indeed superseded real work for many if not most mental health nurses. We contend that anxieties associated with interaction, or lack of interaction, contribute to alienated states for service users and staff within modern care settings. All concerned are vulnerable to the detrimental consequences of denuded or inauthentic relationships (Wright \& Schroeder 2016). Alienating environments contribute to diminished staff morale and poor patient experience, consolidating prevailing and conflictual 'us and them' cultures, further feeding 
processes of othering that sustain legitimation of overly coercive services (see also Fromm 1955).

Moreover, constrained time and resource allocation is exacerbated by an extant neoliberal polity predicated on an unholy trinity of big business, mass media and government. A triumvirate that presently insists public services and the most disadvantaged pay the austerity price for failings of an iniquitous economic system. The neoliberal regime is simultaneously and inextricably entwined with overarching systems of governance and the application of technologies to the relations of care; hugely influential in the organisation of nurses' work (McKeown 1995). These tendencies are exacerbated by framings of risk society and power relations that reify the status of psychiatry, and attendant psy-disciplines (such as nurses), to justify and prioritise a role in policing mental distress (Ingelby 1985, Rose 1985).

We argue that critical sense can be made of this unwholesome state of affairs with recourse to material and post-material social and political theories (see Barnett 2005, Moth \& McKeown 2016; Springer 2012). Illumination can then point to remedial action. Latter-day affinities for enhanced degrees of service user involvement or co-production in the context of mental health care can prefigure more relational, situated alternatives for reorganising care and nurses' work, and these need not be beholden to risk aversion or defensive commitment to paperwork. Without, however, sufficient criticality some of these seemingly providential strategic opportunities may prove to be a fool's errand, with co-opted practices and diluted emancipatory objectives failing to achieve the necessary escape velocity to transcend neoliberalism's oppressive dominance. Ultimately, transformations in care and nurses' work require a political challenge to neoliberalism, and how this plays out in mental health services. One remedy for the crisis in mental health care is to truly democratise services.

\section{The table-top: contemporary mental health care}

Despite the espoused commitment on the part of nursing to therapeutic alliance (Chambers 1998; Cleary et al. 2012a, 2012b; Peplau 1952; Wright 2014), this has been found lacking within psychiatric wards (Cleary 1999; Gilburt et al. 2008; Lelliott \& Quirk 2004; McAndrew et al. 2014; Rose et al. 2015). Staff can become increasingly distant from service users because they effectively prioritise paperwork over other work. This can be for a number of reasons: policy, local protocols and managers expect and insist that certain care records are 
kept in a tidy fashion on a daily basis; staff perceive that failure to comply with record keeping is an abrogation of professional role, might lead to disciplinary action, or render them vulnerable to post hoc scrutiny following critical incidents; or time spent on record keeping constitutes avoidant behaviour, an attempt to manage the emotional labour of care work; all complicated by limited resources.

Especially in over-stretched urban settings, ward care is typified by experiences of staff shortages, significant use of bank and agency staff, over-occupancy, concentration of higher levels of acuity and dependency, violence and subsequent stress for staff (Csipke et al. 2016). Staff face organisational rhythms and practices involving perpetually reacting to events rather than pre-empting them (Cleary 1999). This can precipitate emotional strain and the moral dilemma of understanding what best practice might entail but feeling unable to deliver it. Consequences for patients include at best crushing boredom (Rose 2001) at worst alienation amidst a conflictual and oppositional culture that relates to them as 'other' (Maccallum 2002). Staff and organisational efforts geared towards minimising risk have intruded ever increasing levels of compulsion and coercion into a system already overly dependent upon singular medical or containing interventions (McLaren 2007, Newton-Howes 2010, Vassilev \& Pilgrim 2007).

Ironically, given that paperwork takes up so much nursing time but time spent with service users is at a premium, it is challenging not to conclude that most care records are somewhat fictional. If this is so, then any substantive minimisation of risk may also be called into question. Research into initiatives to more thoroughly involve service users in care planning and coordination activities shows institutional emphasis on formality and procedural aspects whilst patients remain mostly passive in the face of staff's risk management priorities (Coffey et al 2016). Furthermore, risk assessment and management proceeds with recourse to available 'fictions' which assist workers to accommodate themselves to realities of indeterminacy and ambiguity; faith in normative certainties is maintained in an implicit dismissal of inadequacies and uncertainties of prediction within an overriding context of risk aversion (Coffey et al 2016). Taking this to a logical conclusion, perhaps spending more time in face to face dialogue and support, or simply occupying the same space, would be a more appropriate risk management tactic, regardless of the extensiveness of any record keeping. At the very least, an empirical basis for relevant practices and examination of alternatives may be merited. 
Despite some notable initiatives to protect time for face to face encounters and expand meaningful activities (Gamble et al. 2010; Janner 2007), there is ample evidence that contact is demarcated spatially and temporally. Rose and colleague's (2013) study of life on acute inpatient wards found, amongst other things, that whilst service users experienced nurses as distant, coercive and uncaring the nurses expressed powerlessness to deliver on therapeutic aspirations due to administrative burden. The authors also considered power relations, viewing the nurses as marginalised within prevailing medical and managerial hierarchies. Lack of face to face contact time between nurses and service users was upsetting for all, with staff experiencing conflicting emotions that ultimately exacerbated the experience in a vicious circle of avoidance with deleterious consequences:

The main cause of this 'burnout' appeared to arise from limited internal coping skills and from the need for staff to protect themselves emotionally from the complexities of individual service users in their care (Rose et al. 2013: 4)

In such a scenario, avoidant behaviour can serve to justify time spent on nursing paperwork, and this time away from care precipitates more interaction anxiety and avoidance. Not to admit to the truth of this would be further evidence for nursing's capacity for self-deception.

\section{Neoliberalism: the con is upon us}

Extensive and erudite criticisms of neoliberalism proliferate in the wider literature (Crouch 2011; Quiggin 2010; Springer 2016) and the health and mental health context (see De Vogli 2011; Orton 2015; Moncrieff 2008; Ramon 2008; Teghtsoonian 2009). It is not our intention to revisit these in depth or breadth, instead we explore how the critique is germane to the failings of mental health care we have identified. The value of doing so is this critique also points to means by which our historically contingent circumstances can be redeemed.

Before a state of neoliberalism had ever been identified or named, various scholars with an interest in mental health, and others more concerned with society at large had noted tendencies associated with 'late' capitalism (Jameson 1991). These historical developments heralded exacerbations of social inequalities and power distribution and evolved into the form of political-economy now recognised as neoliberalism, typified by extreme laissez faire economics, privatisation, deregulation, and austerity. In the context of healthcare this is often 
associated with exercise of control via models of administrative governance such as "new public management' (Carney 2008). Under this system people are assumed to embody a particular form of autonomous individualism, driven by the pursuit of choice to play their role in the allocation of resources within free markets. These commentators also observed the means by which powerful elites would subtly consolidate power and exert control over those whose rights and interests were being eroded. Hence, Michel Foucault pointed out the central role of psychiatry and the psy-professions in maintaining social order through the identification, calibration and surveillance of individuals deemed to represent deviation from normalcy under a wider rubric of medicalising and commodifying mental distress (Esposito \& Perez 2014; Fries 2008; Rose 1990). The fact nurses are inescapably bound up with and responsible for maintaining this social function does not demand they comprehend this is the case. This critique identifies core psychiatric practices such as diagnosis, assessment, care planning, symptom and behaviour monitoring as critical to the exercise of a social control function.

Moreover, whilst psychiatric services become ever more focused upon risk management and increasingly risk averse, this occurs against a backdrop of a more broadly defined risk society. The archetypal autonomous individual of neoliberalism is an uneasy depiction of the actuality of conventionally understood and approved patient experiences, subject to professionally determined decisions with concomitant expectations of passivity and deference to psychiatric power. Embroiled within such contradictory expectations is the potential to consider service users themselves as blameworthy for negative consequences of behaviour (Coffey et al. 2106).

Under risk society, governments themselves begin to define their central task as risk minimisation and, paradoxically, their political interests are bolstered by simultaneously stoking public fears whilst rhetorically holding out the promise that protection can be provided for. This Janus-like stance affords politicians opportunities to abrogate from providing any progressive manifesto for a better world (Curtis 2004). Interestingly, these political machinations are best served with recourse to an appropriate bogeyman; today's prime example being international terrorism, but dangerous madness also suffices (McKeown \& Stowell Smith 2006). Regardless, mental health care under such a system becomes increasingly subject to close supervision and monitoring, including by external 'quality' agencies, and this surveillance further amplifies an imperative for detailed records. 
Peter Sedgwick's (1982) seminal text, Psycho Politics, pre-empted debates over neoliberalism in the course of reacting to its emergence within 1980s Thatcherism. He called for a new politics of mental health, synthesising Marxist historical materialism with anarchist prefiguring of democratised social relations. As such, Sedgwick made the case for learning the lessons of both material and post-material critiques of society and mental health care. An overriding aim was to make the continued case for state level welfare and support for the mentally distressed. Indeed, simplistic anti-psychiatry critiques were dismissed because they offered the political right a ready-made prescription for wholesale dismantling and retraction of services. This is not to say that Sedgwick was happy with the form and substance of such services. He certainly was not: instead advocating for fundamental, wholesale change that could be forged in relational, situated ways without denying the importance of seriously addressing material disadvantage. Sedgwick's transformative vision may thus be realised without jettisoning the value of historical materialism in the rush to throw out the bathwater of simplistic economic determinism.

The tensions between contemporary Marxist and anarchist strategic thinking on the most appropriate response to neo-liberalism are evident in much current writings in the social and political sciences and, interestingly for mental health care, human geography, where the focus is on the politics and usage of place and space. Notable amongst these authors is John Holloway (2002) who from within a Marxist tradition decries deterministic approaches to urge us to Change the World Without Taking Power. For Holloway, the opportunities and contradictions for activists reside in the fact that their activism is always both 'in and against' capitalism. Hence, the potential for revolutionary transformations may be less about ruptural appropriation of state power and more suitably located in smaller scale, everyday refusals to succumb to the power of neoliberal capitalism - this is what Holloway refers to as the scream', or 'anti-power'. In a similar vein, scholars of public services have noted that despite the seeming omnipresence of neoliberalism there is ample scope to do something different in the interstitial spaces of life, society and institutions, where the powerful are not always looking (Bondi 2005, Clarke 2007); resonating somewhat with notions of street level bureaucracy (Lipsky 1969, Wells 2007). Similarly, Law and Mooney (2006) have remarked upon the virtues of recalcitrance within social movements aspiring to transformational change, and there is certainly ample scope for rebellion on the part of service users (and potential staff allies) faced with the lack of choices attendant upon compulsion and coercion into singularly biologically orientated care and treatment regimes (McKeown 2016a; McKeown et al. forthcoming). 
In the eye-catchingly titled provocation, Fuck Neoliberalism, and a series of other publications, Simon Springer $(2008,2014,2016)$ makes the case for prefigurative forms of living that demonstrate how human needs can be met equitably and politics organised collectively without degrading either the environment or our basic humanity. In this sense, Springer and Sedgwick draw upon a similar provenance of ideas, going back to Kropotkin, privileging human, relational attributes as the engine for transformative change in a modelling of the world we would like to see in the course of trying to achieve it. Springer's deployment of the F-word is purposeful, highlighting the fact that any possible offence at alleged 'bad language' pales into insignificance against the very real offensiveness of the impact of neoliberalism upon the lives of the disadvantaged and the very fabric of our living space.

\section{Gullible nursing?: deceptions, passivity and compliance in the face of a crisis}

The consequences of the neoliberal order of things include substantial alienation of the psyworkforce. Nurses who wish to identify with caring find themselves alienated from their very 'species being' as nursing work is organised in ways that squeeze out possibilities for human connectedness (McKeown et al. 2010). Arguably, the vast majority of the nursing workforce is relatively ignorant of the entanglement of neoliberal forces with the day to day organisation of their work, or at the very least they are passive and compliant in the face of it. The notion that care planning endeavours are essentially valuable, or indeed have utility in minimising risk, may be an illusion, grounded in fictional narratives surrounding record keeping and the records themselves (Coffey et al. 2016), or outright delusional. The fact that a degree of selfpreservation may be attributable to the deceptions we afford ourselves concerning the value of care planning activity does not excuse the privileging of paperwork over real therapeutic endeavour.

Similarly, some of our cherished sacred cows, such as commitments to recovery and participatory involvement initiatives, which offer a balm to our wounded professional identity, may be much less virtuous than they first appear if we consider the socio-political context (Harper \& Speed 2012; Howell \& Voronka 2012). McWade (forthcoming) goes further to argue that such allegedly progressive developments in mainstream mental health care are inescapably enmeshed with key social and political goals of neoliberalism. In the extreme, therapies and therapists are put to the service of the labour market and assessment of work 
capability under new regimes of psycho-compulsion (Thomas 2016). Seen through this lens, recovery policy is designedly discriminatory and certain classes of people, such as ethnic minorities or poor people, will inevitably be failed more than others by services. Survivor activism may have precipitated recovery as policy, but this has served to conceal psychiatry's legitimacy shortcomings, shoring up practices of domination (see also Tyler 2010, 2013). Psychiatry thus plays its designated part within neoliberal systems of detention, accumulating profit at the expense of alienated, dispossessed and 'failed' individuals.

Psychiatric power to classify madness and distress as illness, legitimating paternalistic approval of coercion and control, assists in strengthening neoliberal interests. This is further consolidated within a 'self' celebratory society in thrall to market forces, wherein mental illness refers to individual rather than collective or social problems. Arguably, nursing's conscious or unconscious complicity in this state of affairs indicates a degree of naivety bordering upon professional gullibility. Hence, we are the inheritors of a set of tasks, including care planning, commensurate with neoliberal and bio-psychiatric dominance that we bolster, despite certain grumblings, through continuing passive compliance.

\section{Listening for a squawk of resistance}

Where then is the squawk from beleaguered nurses and other psy-professionals? There are some notable exemplars: the Critical Psychiatry Network, Psychologists Against Austerity, and the Critical Mental Health Nursing Network, amongst a few. Similarly, health and public service trade unions are often vociferous campaigners against cuts, but arguably require a more sophisticated politics of mental health and somewhat less hubris to forge the necessary alliances with survivor and service user activism required to pursue change (McKeown et al. 2014a). Notwithstanding the energies put into various campaigns, or grassroots rumblings of discontent, any collective squawk from mental health nurses seems to be very much muted at present but has great potential to grow into something more powerfully meaningful.

Under neoliberalism, Western democracies, their health care services and trade unions face a multiplicity of interconnected legitimacy shortcomings. An inevitable consequence is the precipitation of protest and contemplation of alternative futures. The various crises of legitimation include democratic deficits in the state at national and local levels, a crisis in care and alleged lack of compassion amongst the workforce (Francis 2013), and trade union 
decline associated with loss of faith in internal democratic structures (Hyman 2007). Bauman (2000) posits a state of liquid modernity that has come to typify the experience of life under mature capitalistic societies. Public services in particular suffer predictably negative consequences of marketization and privatisation, including heightened uncertainties and insecurities for the workforce with subsequent damage in terms of continuity and fragmentation of caring relationships (Randall \& McKeown 2013).

Mental health services are perennially starved of resources and organised around a medical model that upholds mass compulsion and coerced treatment, precipitating specific criticisms and pro-active consideration of alternatives. Thus bio-psychiatry is subject to a quite particular legitimacy crisis, subject to powerful questioning on its own scientific terms with credible critique of the evidence for treatments such as medication (Moncreiff 2008, Whittaker 2010). The resource squeeze on public services has significantly contributed to a workforce crisis, with disquiet over establishment of safe staffing levels. Such concerns have largely referenced general adult healthcare; with mental health services (perhaps conveniently) neglected in much of the discussion.

In some regards this has resulted in the beginnings of a squawk, but arguably the levels and volume of dissent have been insufficient or energies side-tracked into circular debates regarding the calibration or evidencing of staffing profiles. Neoliberal regimes favour elaborate mechanisms for scrutiny and calculation that promulgate a strange admixture of illusory confidence and abject anxieties concerning staffing-levels. The pretence of systematisation fosters a veneer of safety to present to auditors and commissioners whilst a necessity of defensive practice is reinforced in the face of insufficiencies and high turnover of staff.

Taken together, these crises have provoked critical thinking to frame alternative forms of care that hold promise to meet Sedgwick's demand for large-scale responses to mental distress. A number of these, such as Soteria, earlier thinking around Therapeutic Communities and the more recent Open Dialogue, whilst not panaceas, share a common characteristic of privileging democracy, and if at all possible, minimising coercion and medication (Mosher 1999, Seikkula et al. 2011, Spandler 2009, Winship 2013). 
The notion of user voice has achieved, at least at the level of rhetoric, a certain prominence in policy and practice, with examples of involvement extending beyond direct care into education and research (Lowes \& Hulatt 2013, McKeown \& Jones 2014, Terry 2012). Somewhat paradoxically, critically minded service users have capitalised on a distinctly consumerist turn in social policy attendant on neoliberal assertions of the primacy of individualism and personal choice. A consumerist framing perhaps explains both the general lack of transformative impact of what passes for standard user involvement initiatives (see Suzanne Hodge 2005, 2009) and the ever present hazard of co-option. Cooke \& Kothari (2002) view such participation as akin to a new form of tyranny, too readily incorporated into established systems of governance and control. Yet, whilst not yet revolutionary there are also undoubted contemporaneous successes of more creative and deliberative forms (McKeown et al. 2014b). To some extent this supports the view of commentators such as Clarke (2007) who defy pessimism regarding the possibilities for overthrowing neo-liberal hegemony, highlighting the potential of recalcitrant positioning within the cracks and interstices of public services. Similarly, Saario (2012) has noted the subtle ways in which mental health nurses can resist unwanted aspects of new managerialism.

We turn now to consider opportunities for moving beyond a rhetoric of participation and voice towards a logic of democratisation that involves staff and service users in shaping the very ways in which care work is organised. Within such a frame, the very idea of individualised care planning may become redundant, or at least credibly questioned, in a context of more collectivised intervention.

\section{Turning the tables: Democratising the mental health workplace}

At least one normative characteristic of officially sponsored user involvement initiatives is that they are almost universally demarcated from forums for staff voice within organisational structures. It can be argued that there is value in linking together staff and service user voice initiatives, including the involvement of trade unions, in processes that move beyond simple partnership arrangements towards deeper and more sophisticated democracies in action (McKeown et al. 2016b). Throughout history, other work contexts have offered different forms of workplace democracy, distributed or cooperative control, or enhanced employee voice (Bernstein 2012, Frege 2002, Mathews 1999). To some extent democratised workplaces in mental health care would be compatible with proposed new models of distributed leadership, drawing upon, amongst others, left-commentators such as Paulo Freire (Bevan \& Fairman 2014). 
The organisation and management of work under capitalism has mainly been under hierarchical command structures. Despite some latter tendencies towards more complex organisational forms, capitalism has usually eschewed the argued for benefits for more democratic or participatory forms, on the grounds of ensuring efficiency or defending property rights; though a business case for these has been articulated (Bhattii \& Qureshi 2007, Rogers 2012). The fact that prefigurative democratised workplaces are exceptional exposes certain fallacies implicit to western liberal democracies. Johnson (2006) plausibly poses the question that if citizens have the right to democratically participate in the governance of the State on the basis that those subject to decisions that affect them should have a say in how these decisions come about, then why is this logic not extended to other public spheres, such as employment? Given the impact of globalization and concentration of power and influence away from the State in large corporations, answers to such questions assume added importance.

Our vision for democratised care services is, however, more radical than mainstream prescriptions and, if realised, would constitute tangible workplace democracy, and this would indeed be prefigurative of new ways of organising healthcare work and nurture novel, similarly democratised, therapies (Proctor 2016). Under democratised workplaces we could, and must, negotiate relational forms of work that minimise or dispense with paperwork. The Open Dialogue process has arguably already achieved this to a large extent; with the emphasis upon honest, face to face communication amongst all stakeholders and a commitment to labour-intensive contact, the need to write everything down becomes less essential. Matters of planning are continually part of ongoing dialogue such that roles, actions and impacts are out in the open, present in frequent communication, and, hence, much more tangibly real than a digitised care plan that interested parties, particularly service users, may never actually read, let alone agree the contents.

\section{The scream}

The case for greater democracy is, we believe, the remedy for mental health nursing's legitimacy crisis (McKeown \& White 2015). It is not our purpose to prescribe in detail the precise form new ways of working might take. Rather, we are concerned with making the case for activist tactics that prefigure such ends; particular examples emerging from intensely relation collective acts of creativity and imagination. Hence, the priority for nurses 
and their representative organisations is to begin the work of forging cross-sectional cooperation, seeking the solidarity with service users and other interested parties necessary to fashion a better future.

We have argued that the democratic alternative need not continue to adhere to bureaucratised systems of surveillance and managerialism, negatively exemplified in the distractions and delusions of care planning and other paperwork. Though alternative futures are yet to be fully imagined, ideally these would involve substantial reductions in paperwork and a reorientation of nursing energies into democratic, dialogic face to face interactions with service users. Care planning and co-ordination would become more indivisible from the actual transaction of care, not something that occurs largely in the absence of the care recipient. Care plans themselves would be more meaningful documents, better reflecting service users' needs and wishes. Such alternatives would themselves result from democratised processes of creative co-production, and these in turn could prefigure more fully formed systems of workplace democracy.

New models of workplace democratisation are best suited to post-bureaucratic workplaces, typically staffed by well-paid, high performing, functionally flexible workforces, able to use their own judgement and adapt to change. This vision offers mental health nurses opportunities to more fully actualise an autonomous, caring professional identity. A distinctive nursing practice that potentiates the sort of highly skilled interventions needed to navigate and hold uncertainty in the context of supporting individuals in mental distress and eludes the diminished, standardised, task orientated roles predicated upon subordination to bio-psychiatry. The transformations we propose will need to be organised for, and this in itself will demand campaigning and activist alliances between staff and service user groupings. Because of current asymmetries in power, these goals may seem unduly utopian, but that does not mean they are not realisable. They certainly won't be unless we make a collective start. It is time to raise our squawk into a scream: a wonderfully opportune starting point could be a bonfire of the paperwork. 


\section{References}

Barnett, C., 2005. The consolations of 'neoliberalism'. Geoforum, 36(1), 7-12.

Bauman, Z. (2000) Liquid modernity. Polity Press, Cambridge. [2nd edition 2012]

Beck, U. (1992) Risk Society. Sage, London.

Bee, P., Price, O., Baker, J. and Lovell, K. (2015) Systematic synthesis of barriers and facilitators to service user-led care planning. The British Journal of Psychiatry, 207(2), 104114.

Bernstein, P. (2012) Workplace democratization. Its internal dynamics. Educational Services Publishing, Chelsea, MA.

Bevan, H \& Fairman, S (2014) The new era of thinking and practice in change transformation: A Call to Action for Leaders of Health and Care, NHSIQ (NHS Improving Quality). http://media.nhsiq.nhs.uk/whitepaper/html5/index.html?page=1

Bhattii, K. \& Qureshi, T. (2007) Impact of employee participation on job satisfaction, employee commitment and employee productivity. International Review of Business Research Papers, 3, 2, 54-68.

Bondi, L., 2005. Working the spaces of neoliberal subjectivity: psychotherapeutic technologies, professionalisation and counselling. Antipode, 37(3), 497-514.

Carney, T., 2008. The mental health service crisis of neoliberalism—An antipodean perspective. International Journal of Law and Psychiatry, 31(2), 101-115.

Chambers, M. (1998) Interpersonal mental health nursing: Research issues and challenges. Journal of Psychiatric and Mental Health Nursing, 5, 203-211.

Clarke, J. (2007) Citizen-consumers and public service reform: at the limits of neoliberalism? Policy Futures in Education, 5, 239-248.

Cleary, M. (1999) 'Something always comes up': nurse-patient interaction in an acute psychiatric setting. Journal of Psychiatric and Mental Health Nursing, 6(6), 469-477.

Cleary, M., Horsfall, J., O'Hara-Aarons, M., Jackson, D. and Hunt, G.E. (2012a) Mental health nurses' perceptions of good work in an acute setting. International Journal of Mental Health Nursing, 21(5), 471-479. 
Cleary, M., Hunt, G.E., Horsfall, J. and Deacon, M. (2012b) Nurse-patient interaction in acute adult inpatient mental health units: A review and synthesis of qualitative studies. Issues in Mental Health Nursing, 33(2), 66-79.

Coffey, M., Cohen, R., Faulkner, A., Hannigan, B., Simpson, A. \& Barlow, S. (2016) Ordinary risks and accepted fictions: how contrasting and competing priorities work in risk assessment and mental health care planning. Health Expectations.

Cooke, B. \& Kothari, U. (2002) Participation: The New Tyranny? London: Zed.

Crouch, C. (2011) The Strange Non-death of Neoliberalism. Cambridge: Polity.

Csipke, E., Williams, P., Rose, D., Koeser, L., McCrone, P., Wykes, T. \& Craig, T. (2016) Following the Francis report: investigating patient experience of mental health in-patient care. The British Journal of Psychiatry, DOI: 10.1192/bjp.bp.115.171124.

Curtis, A. (2005) The Power of Nightmares. BBC TV Documentary Series.

De Vogli, R. (2011) Neoliberal globalisation and health in a time of economic crisis. Social Theory \& Health, 9(4), 311-325.

Esposito, L. \& Perez, F.M. (2014) Neoliberalism and the commodification of mental health. Humanity \& Society, 38(4), 414-442.

Francis, R (2013) Report of the Mid Staffordshire NHS Foundation Trust Public Inquiry. Stationary Office, London.

Frege, C.M. (2002) A critical assessment of the theoretical and empirical research on German works councils. British Journal of Industrial Relations, 40(2), 221-248.

Fries, C.J. (2008) Governing the health of the hybrid self: Integrative medicine, neoliberalism, and the shifting biopolitics of subjectivity. Health Sociology Review, 17(4), 353-367.

Fromm, E. (1955) The Sane Society. New York: Holt, Rinehart and Winston.

Gamble, C., Dodd, G., Grellier, J. et al. (2010). Zoning: Focused support: A Trust wide implementation project. Journal of Psychiatric and Mental Health Nursing, 17 (1), 79-86.

Gilburt, H., Rose, D. \& Slade, M. (2008) The importance of relationships in mental health care: A qualitative study of service users' experiences of psychiatric hospital admission in the UK. BMC Health Services Research, 8(1), 1. 
Goffman, E. (1952) On cooling the mark out; some aspects of adaptation to failure. Psychiatry, 15, 4, 451-463.

Harper, D. \& Speed, E., 2012. Uncovering recovery: The resistible rise of recovery and resilience. Studies in Social Justice, 6(1), 9.

Hodge, S. (2005) Participation, discourse and power: a case study in service user involvement, Critical Social Policy, 25, 164-179.

Hodge, S. (2009) User involvement in the construction of a mental health charter: an exercise in communicative rationality? Health Expectations, 12, 251-261.

Holloway, J. (2002) Change the world without taking power. London: Pluto Press.

Howell, A. \& Voronka, J., 2012. Introduction: The politics of resilience and recovery in mental health care. Studies in Social Justice, 6(1), 1.

Hyman, R. (2007) How can trade unions act strategically? Transfer, 13, 2, 193-210.

Ingleby, D. (1985). Professionals as Socialisers: the 'Psy-Complex'. In A. Scull \& S. Spitzer (Eds.) Research in law, deviance and social control. New York: Jai Press. pp.79-109

Jameson, F. (1991) Postmodernism, or, the cultural logic of late capitalism. London, Verso. Janner, M. (2007) From the inside out: STAR WARDS - lessons from within acute inpatient wards. Journal of Psychiatric Intensive Care, 3 (2), 75-78.

Johnson, P. (2006) Whence democracy? A review and critique of the conceptual dimensions and implications of the business case for organizational democracy. Organization, 13(2), 245-274.

Law, A. \& Mooney, G. (2006) Social capital and neo-liberal voluntarism. Variant, 26, 18-20.

Lelliott, P. \& Quirk, A. (2004) What is life like on acute psychiatric wards? Current Opinion in Psychiatry, 17(4), 297-301.

Lipsky, M. (1969) Toward a theory of street-level bureaucracy (IRP Discussion Papers No. 48-69). Madison, WI: Institute for Research on Poverty (IRP), University of Wisconsin.

Lowes, L. \& Hulatt, I. (eds) (2013) Involving service users in health and social care research. London, Routledge.

Maccallum, E. (2002) Othering and psychiatric nursing. Journal of Psychiatric and Mental Health Nursing, 9, 87-94. 
Mathews, R. (1999) Jobs of our own: Building a stakeholder society. London, Comerford and Miller.

McAndrew, S., Chambers, M., Nolan, F., Thomas, B. and Watts, P. (2014) Measuring the evidence: Reviewing the literature of the measurement of therapeutic engagement in acute mental health inpatient wards. International journal of mental health nursing, 23(3), 212-220. McKeown, M. (1995) The transformation of nurses' work? Journal of Nursing Management, $3,2,67-73$.

McKeown, M. (2016a) Stand up for recalcitrance! International Journal of Mental Health Nursing,

McKeown, M. (2016b) Educate, agitate, organise! The democratic challenge facing workers and survivors. Asylum: the magazine for democratic psychiatry (30th Anniversary Issue),

McKeown, M., Cresswell, M. \& Spandler, H. (2014a) Deeply engaged relationships: alliances between mental health workers and psychiatric survivors in the UK. In B. Burstow, B. A. LeFrancois and S. L. Diamond (eds) Psychiatry disrupted: theorizing resistance and crafting the revolution. Montreal, QC: McGill/Queen's University Press.

McKeown, M. \& Jones, F. (2014) Service user involvement. In I. Hulatt (ed) Mental health policy for nurses. London, Sage[p;'.

McKeown, M., Jones, F., Wright, K., Spandler, H., Wright, J., Fletcher, H., Duxbury, J., McVittie, J. \& Turton, W. (2014b) It's the talk: a study of involvement initiatives in secure mental health settings. Health Expectations, 19, 570-579.

McKeown, M., Malihi-Shoja, L. \& Downe, S. \& The Comensus Writing Collective (2010) Service user and carer involvement in education for health and social care. Wiley-Blackwell, Oxford.

McKeown, M., Poursanidou, D., Able, L., Newbigging, K., Ridley, J. \& Kiansumba, M. (2013) Independent Mental Health Advocacy: Still Cooling Out the Mark? Mental Health Today, November/December, 20-21.

McKeown, M., Scholes, A., Jones, F. \& Aindow, W. (forthcoming) Coercive practices in mental health services: stories of recalcitrance, resistance and legitimation. in A. Daley, L. Costa \& P. Beresford (Eds) Madness, violence and power. University of Toronto Press, Toronto.

McKeown, M. \& Stowell-Smith, M. (2006) The Comforts of Evil. In T. Mason (ed) Forensic Psychiatry. Humana Press. (pp. 109-134). 
McKeown, M. \& White, J. (2015) The future of mental health nursing: are we barking up the wrong tree? Journal of Psychiatric and Mental Health Nursing, 22(9), 724-730.

McLaren, N. (2007) Humanizing madness: Psychiatry and the cognitive neurosciences. Ann Arbor, Ml: Loving Healing Press.

McWade, B. (forthcoming) Recovery-as-policy as a form of neoliberal state making. Intersectionalities: A Global Journal of Social Work Analysis, Research, Polity and Practice. Moncrieff, J. (2008) Neoliberalism and biopsychiatry: A marriage of convenience. Liberatory psychiatry: Philosophy, politics and mental health, 9, 235-256.

Mosher, L. (1999) Soteria and other alternatives to acute psychiatric hospitalization: a personal and professional review. Journal of Nervous and Mental Disease, 187, 142-9.

Moth, R. \& McKeown, M. (2016) Realising Sedgwick's vision: theorising strategies of resistance to neoliberal mental health policy. Critical \& Radical Social Work,

Newton-Howes, G. (2010) Coercion in psychiatric care: where are we now, what do we know, where do we go? The Psychiatrist, 34, 217-220.

Orton, M. (2015) 'Something's not right: insecurity and an anxious nation' London: Compass. Available from: www.compassonline.org.uk/wp-content/uploads/2015/01/CompassSomethings-Not-Right.pdf

Peplau, H. (1952) Interpersonal Relationships in Nursing. New York: G. P. Putnam \& Sons.

Proctor, H. (2016) Lost Minds Sedgwick, Laing and the politics of mental illness. Radical Philosophy 197 (May/June 2016)

Quiggin, J. (2010) Zombie economics: how dead ideas still walk amongst us. Princeton: Princeton University Press.

Ramon, S. (2008) Neoliberalism and its implications for mental health in the UK. International journal of law and psychiatry, 31(2), 116-125.

Randall, D. \& McKeown, M. (2013) Failure to care: nursing in a state of liquid modernity? Journal of Clinical Nursing, 23: 766-767.

Rogers, J. (2012) Productive democracy. In J. De Munck, I. Ferreras, C. Didry \& A. Jobert (eds) Renewing Democratic Deliberation in Europe: The Challenge of Social and Civil Dialogue. pp. 71-92. 
Rose, D. (2001) Users' voices: the perspectives of Mental Health Service users on community and hospital care. London: Sainsbury Centre for Mental Health.

Rose, D., Evans, J., Laker, C. \& Wykes, T. (2015) Life in acute mental health settings: experiences and perceptions of service users and nurses. Epidemiology and Psychiatric Sciences, 24, 90-96.

Rose, G. (1993) Feminism \& geography: The limits of geographical knowledge. U of Minnesota Press.

Rose, N. (1985). The Psychological Complex: Psychology, Politics and Society in England 1869-1939. London: Routledge and Kegan Paul.

Rose, N. (1990). Governing the soul: The shaping of the private self. London: Routledge.

Saario, S. (2012) Managerial reforms and specialised psychiatric care: a study of resistive practices performed by mental health practitioners. Sociology of health \& illness, 34(6), 896910.

Sedgwick, P. (1982) Psycho Politics. London: Pluto.

Seikkula, J., Alakare, B., \& Aaltonen, J. (2011) The Comprehensive Open-Dialogue Approach in Western Lapland: II. Long-term stability of acute psychosis outcomes in advanced community care. Psychosis, 3, 3, 192-204.

Simpson, A. (2005) Community psychiatric nurses and the care co-ordinator role: squeezed to provide 'limited nursing'. Journal of Advanced Nursing, 52, 689-699.

Spandler, H. (2009) Spaces of psychiatric contention: a case study of a therapeutic community. Health \& Place, 15, 672-678.

Springer, S. (2016) Fuck neoliberalism. ACME: An International Journal for Critical Geographies, 15(2): 285-292

Springer, S. (2012) Neoliberalism as discourse: between Foucauldian political economy and Marxian poststructuralism. Critical Discourse Studies, 9(2), 133-147.

Springer, S. (2008) The nonillusory effects of neoliberalisation: linking geographies of poverty, inequality, and violence. Geoforum, 39(4), 1520-1525.

Springer, S. (2014) Neoliberalism in denial. Dialogues in Human Geography, 4(2), 154-160. 
Teghtsoonian, K., 2009. Depression and mental health in neoliberal times: A critical analysis of policy and discourse. Social Science \& Medicine, 69(1), 28-35.

Terry, J. (2012) Service user involvement in pre-registration mental health nurse education classroom settings: a review of the literature. Journal of Psychiatric and Mental Health Nursing, 19(9), 816-829.

Thomas, P. (2016) Psycho politics, neoliberal governmentality and austerity. Self \& Society, DOI: $10.1080 / 03060497.2016 .1192905$

Tyler, I. (2010) Designed to fail: a biopolitics of British citizenship. Citizenship studies, 14(1), 61-74.

Tyler, I. (2013) Revolting subjects: Social abjection and resistance in neoliberal Britain. London: Zed Books.

Vassilev, I. \& Pilgrim, D. (2007) Risk, trust and the myth of mental health services. Journal of Mental Health, 16, 347-357.

Wells, J. (2007) Priorities, 'street level bureaucracy' and the community mental health team. Health and Social Care in the Community, 5, 333-342.

Whittaker, R. (2010) Anatomy of an Epidemic: Magic Bullets, Psychiatric Drugs and the Astonishing Rise of Mental IIIness in America. Broadway Books, New York.

Winship, G. (2013) A genealogy of therapeutic community ideas: the influence of the Frankfurt School with a particular focus on Herbert Marcuse and Eric Fromm. Therapeutic Communities: The International Journal of Therapeutic Communities, 34(2/3), 60-70.

Wright, K. (2014) Maternalism: a healthy alliance for recovery and transition in eating disorder services. Journal of Psychiatric and Mental Health Nursing, 22 (6). pp. 431-439.

Wright, K. \& Schroeder, D. (2016) Turning the Tables. Cambridge Quarterly of Healthcare Ethics, 25, pp 219-227. doi:10.1017/S0963180115000523. 